\title{
DISTRIBUTION PATTERN OF MACROINVERTEBRATE FUNCTIONAL FEEDING GROUPS IN THE STEELPOORT RIVER, SOUTH AFRICA
}

\author{
MAKGOALE, M. M. ${ }^{1}$ - AdDO-BediAKO, A. ${ }^{*}-$ AYISI, K. K. ${ }^{2}$ \\ ${ }^{1}$ Department of Biodiversity, University of Limpopo \\ Private Bag X1106, Sovenga 0727, South Africa \\ ${ }^{2}$ Risk and Vulnerability Science Centre, University of Limpopo \\ Private Bag X1106, Sovenga 0727, South Africa \\ *Corresponding author \\ e-mail: abe.addo-bediako@ul.ac.za; phone:+27-15-268-3145; ORCID: 0000-0002-5055-8315 \\ (Received 12 $2^{\text {th }}$ Jul 2021; accepted 20 $0^{\text {th }}$ Sep 2021)
}

\begin{abstract}
The various human activities along the Steelpoort River in South Africa are causing changes in water quality and affecting the distribution of macroinvertebrate functional feeding groups (FFG). The objectives of this study were to assess the spatial and temporal distribution of FFG of macroinvertebrates and to determine if the community structure corresponds to the River Continuum Concept (RCC). The distribution of the FFG varied significantly among sites and the variation was related to the different characteristics of the sites. The collector-gatherers were the most abundant functional feeding group at Site 1, collector-filterers were the most dominant group at Site 4 and Site 5, predators were the most dominant group at Site 2, Site 3 and Site 6. Shredders were least represented at all sites of the river. Seasonally, the collector-gatherers were dominant in winter, collector-filterers were dominant in spring and predators were the dominant group in autumn and summer. The study showed that the distribution of FFG was not in conformity to the RCC. The results suggest that land use changes in the catchment is affecting the FFG distribution pattern. It is therefore important that policies governing land use changes should take into account the impact on the macroinvertebrate community.
\end{abstract}

Keywords: bioindicators, functional feeding groups, land use changes, riparian disturbance, water quality

\section{Introduction}

Freshwater systems are under constant pressure due to anthropogenic activities, such as agriculture, urbanization, industries and mining ( $\mathrm{Li}$ et al., 2018; Chen et al., 2019; Addo-Bediako, 2020). Land-use activities in river catchments have been linked to water quality deterioration, which can affect the composition and diversity of aquatic biota including benthic macroinvertebrates (Munyika et al., 2014).

Aquatic macroinvertebrates constitute an important component of secondary production within freshwater ecosystems and are integrated into the structure and function of their habitats ( $\mathrm{Li}$ et al., 2010). They are therefore expected to vary consistently in relation to the intensity of disturbance in an ecosystem (Dalu et al., 2017). They are good bioindicators because they continuously dwell in water and they respond to every change they encounter in their environment, such as pollution (Santhosh and Ashadevi, 2017). Different taxa of macroinvertebrates respond differently to environmental stressors and are therefore considered as good bioindicators (Rasifudi et al., 2018). Information on macroinvertebrates is important for a long-term analysis of changes in water quality and may reflect historical processes such as stream 
degradation, pollution, discharge variations and silting (Wright and Ryan, 2016; Castro et al., 2018).

Benthic macroinvertebrates as bioindicators in habitat monitoring programs use basic metrics such as abundance, taxa richness and diversity, however, many biomonitoring programs are also considering a functional approach based on Functional Feeding Groups (FFGs) (Fu et al., 2016; Jun et al., 2016; Kim et al., 2016; Fierro et al., 2017). The FFG classification is based on the food consumed and also considers the morphological and behavioural characteristics used in the food acquisition (Ramirez and Gutiérrez-Fonseca, 2014). The functional feeding groups reflect the four most important food resources found in streams: periphyton, coarse particulate organic matter (CPOM), fine particulate organic matter (FPOM) and animal prey. Shredders feed on coarse particulate organic matter, scrapers consume algae and microbes attached to the coarse particulate organic matter, collector-filterers and collector-gatherers filter the fine particulate organic matter from the water column and directly from the substrate, and predators consume animals or some of their parts (Merritt et al., 2017; Cummins, 2018).

The River Continuum Concept (RCC) is widely used to explain the functioning of lotic ecosystems and predicts how relative FFG abundance changes along a river gradient (Vannote et al., 1980). The RCC proposes that community structure should shift from an allochthonous in the headwater to an autochthonous in the downstream of the river, as the river widens and algal production increases (Allan and Castillo, 2007). Functional composition is therefore necessary for management actions to enhance ecosystem functioning (Ferreira et al., 2012; Meira et al., 2021). This approach is seen to provide more accurate assessment of water quality and ecological integrity of rivers, which indeed could be used for conservation and restoration strategies in managing river ecosystems (Príncipe et al., 2010).

The Steelpoort River, like many South African rivers suffers from water loss, degradation, and poor water quality due to various human activities such as agriculture, mining, industries and informal settlements in the catchment (Dallas, 2007). These have resulted in a wide range of disturbances in the river and its riparian vegetation which can affect the distribution and diversity of aquatic biota, such as macroinvertebrates. The Steelpoort River was selected for this study because of the rapid increase in mining activities and human population in the area, which are putting a lot of pressure on the local natural resources, such as the Steelpoort River (Ashton and Dabrowski, 2011). The objectives of the study were to assess the effects of land use changes on spatio-temporal distribution of the functional groups of benthic macroinvertebrate communities and to determine if FFG conform to the River Continuum Concept (RCC). It is envisaged that the results of the study would be used to design proper conservation tool in the river system. The hypothesis tested was that due to land use changes affecting the river, the macroinvertebrate functional feeding groups would not fully conform to the river continuum concept (RCC).

\section{Materials and methods}

\section{Study area}

The Steelpoort River sub-catchment is one of the four sub-catchments of the Olifants River Catchment in South Africa and covers an area of about 7,139 $\mathrm{km}^{2}$ (Stimie et al., 2001). Summers are usually warm with mean daytime temperatures vary between 19 and $22{ }^{\circ} \mathrm{C}$ and mean winter temperatures are between 13 and $19^{\circ} \mathrm{C}$ (Stemie et al., 
2001). The mean annual rainfall of the area is between 630 and $1000 \mathrm{~mm}$. Rainfall occurs predominantly in summer months (December to February). According to DWAF (1995), the water quality of the middle Steelpoort sub-catchment in both surface and ground water is being threatened by an increasing level of contaminations from mining, industrial, agricultural and residential sources. The Steelpoort River basin is characterized mainly by mining and agricultural activities (Van Veelen and Dhemba, 2011). The mining and industrial activities include chrome, coal, granite, magnesite, alluvial gold, platinum and vanadium mines concentrated in the upper sub-catchment (Stimie et al., 2001).

This study was conducted in summer (February), autumn (April), winter (July) and spring (October) of 2019. Samples were collected at six selected sites potentially receiving different forms of pollution along the river. Site 1 was located upstream with little human activities, though the riparian vegetation is disturbed, Site 2, near a human settlement, Sites 3, near farming and human settlement, Site 4, near mines and smelter, Site 5, domestic and industrial activities, and Site 6, settlement and cattle grazing area (Fig. 1). The co-ordinates of the sites are given in Table 1.

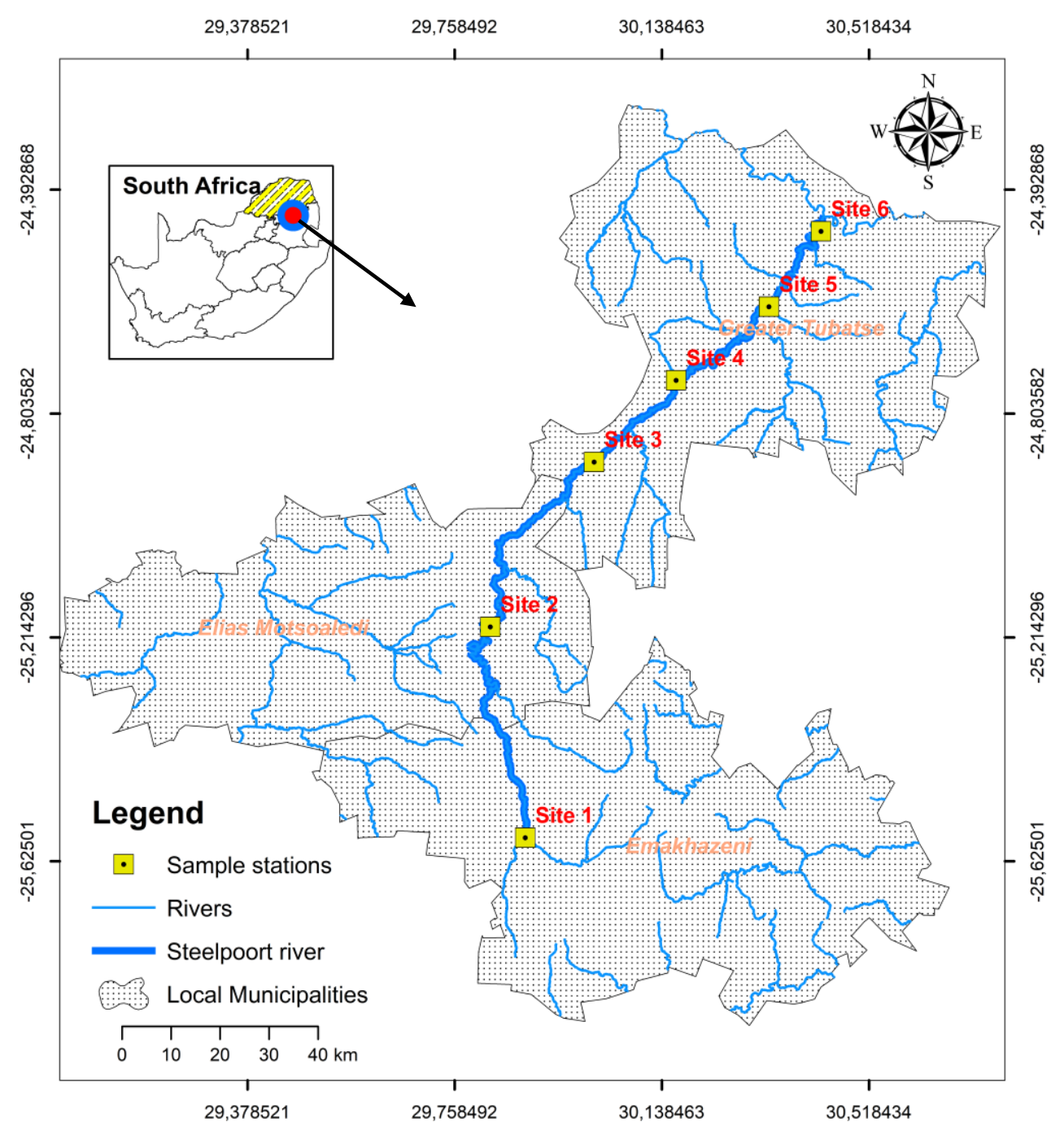

Figure 1. Map of the study area, showing the locations of the sampling sites of the Steelpoort River 
Table 1. Geographical positions of the sampling sites of the Steelpoort River

\begin{tabular}{c|c}
\hline Sites & Geographical positions \\
\hline Site 1 & $25.1010 \mathrm{~S}, 29.84705 \mathrm{E}$ \\
Site 2 & $24.8939 \mathrm{~S}, 30.01717 \mathrm{E}$ \\
Site 3 & $24.83048 \mathrm{~S}, 30.07906 \mathrm{E}$ \\
Site 4 & $24.71797 \mathrm{~S}, 30.20094 \mathrm{E}$ \\
Site 5 & $24.65910 \mathrm{~S}, 30.30202 \mathrm{E}$ \\
Site 6 & $24.64331 \mathrm{~S}, 30.30793 \mathrm{E}$ \\
\hline
\end{tabular}

\section{Water physicochemical variables}

Water samples were collected in $500 \mathrm{ml} 10 \%$ nitric acid pre-treated plastic containers. Collected water samples were kept on ice and sent to the laboratory. The samples were kept at $4{ }^{\circ} \mathrm{C}$ prior to chemical analysis. Nutrient (nitrite, nitrate and phosphate) concentrations and turbidity in the water samples were analysed using spectrophotometer (Merk Pharo 100 Spectroquant ${ }^{\mathrm{TM}}$ ) with Merck cell test kits at the University of Limpopo, Biodiversity Laboratory. Conductivity, $\mathrm{pH}$, salinity, total dissolved solids (TDS), water temperature and dissolved oxygen were measured in situ using a YSI Model 554 portable multi-parameter probe (YSI Inc. Yellow Springs, OH, USA). Flow velocity was measured using a Flo-mate portable flowmeter Model 2000 (Marsh McBirney, Maryland, US). Channel width and water depth were measured using a measuring tape and graduated measuring rod, respectively.

\section{Macroinvertebrate sampling}

Benthic macroinvertebrates were collected using a $30 \mathrm{~cm}$ by $30 \mathrm{~cm}$ sampling net with a $500 \mu \mathrm{m}$ mesh size. The substrate was disturbed by kicking to free macroinvertebrates from the substrate. At each sampling site aquatic habitats (i.e. riffles, pools and vegetated margins) were sampled for approximately $6 \mathrm{~min}$. The samples were preserved in $70 \%$ ethanol in $1 \mathrm{~L}$ polypropylene buckets and transported to the laboratory for identification. The macroinvertebrates were identified to family level except in the case of Oligochaeta and Hirudinea which were identified to class level, using keys by Gerber and Gabriel (2002). The samples were identified with the aid of a stereomicroscope (Leica EZ4) and magnifying glass.

Family level identification was also used to determine the functional feeding group (FFG) in the river except Oligochaeta and Hirudinea (Merritt and Cummins 1996; Cummins et al., 2005). The macroinvertebrates were classified into the following functional feeding groups: Shredders (SH), Gathering Collectors (GC), Filtering Collectors (FC), Scrapers (SC) and Predators (P).

\section{Data analysis}

Analysis of variance (ANOVA) was used to compare water variables among river sites and seasons, after testing for homogeneity of variances (Levene's test, $p>0.05$ ) and normality of distribution (Shapiro-Wilk test, $p>0.05$ ). The same tests were used to assess for differences in macroinvertebrate abundance among sites and seasons. In order to assess whether functional feeding group abundances were different among sites, an analysis of variance was performed, followed by Tukey HSD test. The 
analysis was carried out using Statistica version 10.0 (2007). The macroinvertebrate assemblage composition was determined for each sampling site and seasons using number of taxa $(S)$, total number of individuals and abundance of each taxon. The Shannon-Wiener diversity index $\left(\mathrm{H}^{\prime}\right)$, was used to assess diversity as follows:

$$
\mathrm{H}^{\prime}=\Sigma[(\mathrm{n} / \mathrm{N}) \times \ln (\mathrm{n} / \mathrm{N})]
$$

To assess compositional differences among sites, the percentage of intolerant taxa, Ephemeroptera + Plecoptera + Trichoptera (EPT), which is widely used as an indicator of disturbance to stream communities was also calculated. The South African Scoring System version 5 (SASS5) score, which is the sum of all macroinvertebrates pre-determined taxa tolerance values to pollution within a sample, and the Average Score Per Taxon (ASPT), calculated by dividing the SASS5 score by the sample number of taxa (Dickens and Graham, 2002), were further used to assess the river quality. Cluster analysis and non-metric multi-dimensional scaling (MDS) were used to identify grouping of sampling sites with similar macroinvertebrate assemblages using Euclidean distances (Kruskal, 1964). The percentage contribution of each FFG to the different communities was determined to find out the relative contribution of each group. The influence of physicochemical variables on macroinvertebrate communities and functional feeding groups were determined by canonical correspondence analysis (CCA) using CANOCO version 5.1 software (Ter Braak and Smilauer, 2002).

\section{Results}

\section{Physiochemical variables}

The $\mathrm{pH}$ values observed at the sites varied between 7.1 at Site 5 to 8.9 at Site 3 (Table 2). The mean temperature ranged from $18.3^{\circ} \mathrm{C}$ at Site 6 to $20.6^{\circ} \mathrm{C}$ at Site 3 . The mean oxygen content ranged from $7.4 \mathrm{mg} / \mathrm{l}$ at Site 4 to $8.5 \mathrm{mg} / \mathrm{l}$ at Site 6 . The highest mean conductivity and TDS were recorded at Site 5 and the lowest conductivity and TDS were recorded at Site 1 and Site 2 respectively. Temperature, $\mathrm{pH}$, DO, conductivity, TDS, salinity and turbidity did not differ significantly among the sites (ANOVA, $\mathrm{P}>0.05$ ). However, temperature and turbidity differed significantly among the seasons (ANOVA, $\mathrm{P}<0.05$ ) (Table 3). Mean nitrate concentrations were generally higher at Sites 5 and Site 6, while phosphate concentration was below detection level at all sites. There was a significant seasonal variation in nitrate concentration among the seasons $(\mathrm{p}<0.002)$. There were significant differences in channel width, water depth and velocity among the different sites and seasons.

\section{Macroinvertebrate community structure}

A total of 7,624 individual macroinvertebrates belonging to 39 families, 9 orders and two classes of Annelida (Oligochaeta and Hirudinea) were collected in the Steelpoort River. The dominant taxa were Baetidae (1757), Hydropsychidae (1140), followed by Simuliidae (611). Site 6 had the highest number of individuals of 1708 (22.4\%), followed by Site 3 with 1451 (19.03\%), Site 2 with 1243 (16.30\%), Site 5 with 1230 $(16.30 \%)$, Site 1 with $1020(13.4 \%)$ and Site 4 had the lowest with 972 individuals $(12.74 \%)$ (Table 4). Taxa richness ranged from 25 at Site 4 and Site 5 to 36 at Site 3. 
The EPT index ranged from 5 at Site 5 to 12 at Site 3. Seasonally, the highest abundance was recorded during winter (2660), followed by autumn (2496), spring (1748) and then summer (720). Taxa richness differed among seasons, with the highest taxa richness recorded in Autumn (32) followed by summer (31), Spring (30) and the lowest in winter (29). Hierarchical cluster analysis used to evaluate the faunal similarities among the study sites showed three groups (Fig. 2). Cluster I was composed of Site 1 and Site 3), cluster II, was composed of Site 2 and Site 6, and cluster III, Site 4 and Site 5.

Table 2. Mean water physical variables ( \pm standard deviation) recorded across six sites of the river (range values are in the brackets)

\begin{tabular}{|c|c|c|c|c|c|c|}
\hline Variables & Site 1 & Site 2 & Site 3 & Site 4 & Site 5 & Site 6 \\
\hline & Mean \pm SD & Mean \pm SD & Mean \pm SD & Mean \pm SD & Mean \pm SD & Mean \pm SD \\
\hline Depth (m) & $\begin{array}{l}0.31 \pm 0.31 \\
(0.14-0.54)\end{array}$ & $\begin{array}{l}0.41 \pm 0.17 \\
(0.31-0.61)\end{array}$ & $\begin{array}{l}0.48 \pm 0.05 \\
(0.42-0.52)\end{array}$ & $\begin{array}{l}0.54 \pm 0.25 \\
(0.29-0.87)\end{array}$ & $\begin{array}{c}0.5 \pm 0.07 \\
(0.43-0.59)\end{array}$ & $\begin{array}{l}0.44 \pm 0.11 \\
(0.31-0.54)\end{array}$ \\
\hline Width (m) & $\begin{array}{c}13 \pm 3.26 \\
(9.70-17.5)\end{array}$ & $\begin{array}{l}11.6 \pm 1.9 \\
(9.8-13.6)\end{array}$ & $\begin{array}{c}12.11 \pm 1.92 \\
(10.4-13.8)\end{array}$ & $\begin{array}{c}13.02 \pm 3.0 \\
(9.4-16.7)\end{array}$ & $\begin{array}{c}11.35 \pm 1.18 \\
(10.0-12.7)\end{array}$ & $\begin{array}{l}18.12 \pm 3.9 \\
(10.5-30.0)\end{array}$ \\
\hline Velocity (m/s) & $\begin{array}{l}0.31 \pm 0.21 \\
(0.10-0.56)\end{array}$ & $\begin{array}{l}0.57 \pm 0.21 \\
(0.44-0.70)\end{array}$ & $\begin{array}{c}0.37 \pm 0.12 \\
(0.21-0.5)\end{array}$ & $\begin{array}{l}0.63 \pm 0.39 \\
(0.28-1.15)\end{array}$ & $\begin{array}{l}0.69 \pm 0.16 \\
(0.56-0.93)\end{array}$ & $\begin{array}{l}0.54 \pm 0.32 \\
(0.19-0.90)\end{array}$ \\
\hline $\mathrm{pH}$ & $8.6-8.7$ & $7.7-8.2$ & $7.5-8.9$ & $7.5-8.7$ & $7.1-8.7$ & 7.7-8.7 \\
\hline Temperature $\left({ }^{\circ} \mathrm{C}\right)$ & $\begin{array}{c}19.6 \pm 3.9 \\
(16.3-24.7)\end{array}$ & $\begin{array}{l}20.17 \pm 2.9 \\
(17.3-23.3)\end{array}$ & $\begin{array}{c}20.6 \pm 2.4 \\
(17.8-23.2)\end{array}$ & $\begin{array}{c}19.8 \pm 3.3 \\
(16.2-22-6)\end{array}$ & $\begin{array}{c}18.8 \pm 2.7 \\
(15.9-21.9)\end{array}$ & $\begin{array}{c}18.3 \pm 3.8 \\
(13.8-21.7)\end{array}$ \\
\hline $\mathrm{DO}(\mathrm{mg} / \mathrm{l})$ & $\begin{array}{l}7.9 \pm 1.63 \\
(6.5-10.2)\end{array}$ & $\begin{array}{c}7.5 \pm 0.46 \\
(7.1-7.9)\end{array}$ & $\begin{array}{l}8.2 \pm 1.94 \\
(6.8-11.0)\end{array}$ & $\begin{array}{c}7.4 \pm 0.64 \\
(6.6-8.0)\end{array}$ & $\begin{array}{l}8.3 \pm 1.42 \\
(6.7-10.0)\end{array}$ & $\begin{array}{l}8.5 \pm 1.75 \\
(6.9-11.0)\end{array}$ \\
\hline $\mathrm{EC}(\mathrm{mS} / \mathrm{cm})$ & $\begin{array}{c}227.7 \pm 44.9 \\
(188.0-275.2)\end{array}$ & $\begin{array}{c}267.7 \pm 21.3 \\
(245-294.3)\end{array}$ & $\begin{array}{c}280.3 \pm 30.5 \\
(248-319.9)\end{array}$ & $\begin{array}{l}311.6 \pm 40.1 \\
(285.6-376)\end{array}$ & $\begin{array}{c}324.9 \pm 37.6 \\
(285.6-376)\end{array}$ & $\begin{array}{c}317.3 \pm 22.9 \\
(283.6-334.7)\end{array}$ \\
\hline TDS (mg/l) & $\begin{array}{c}214.8 \pm 66.5 \\
(148.1-305.5)\end{array}$ & $\begin{array}{c}212.9 \pm 55.0 \\
(174.0-294.3)\end{array}$ & $\begin{array}{c}221.1 \pm 66.6 \\
(180.7-319.9)\end{array}$ & $\begin{array}{c}253.7 \pm 76.0 \\
(204-366.4)\end{array}$ & $\begin{array}{c}264.7 \pm 75.9 \\
(214.5-376.0)\end{array}$ & $\begin{array}{c}259.6 \pm 26.9 \\
(224-283.6)\end{array}$ \\
\hline Salinity (\%) & $\begin{array}{l}0.14 \pm 0.05 \\
(0.09-0.22)\end{array}$ & $\begin{array}{c}0.15 \pm \\
(0.13-0.17)\end{array}$ & $\begin{array}{l}0.15 \pm 0.01 \\
(0.13-0.16)\end{array}$ & $\begin{array}{l}0.15 \pm 0.02 \\
(0.13-0.17)\end{array}$ & $\begin{array}{l}0.17 \pm 0.02 \\
(0.16-0.19)\end{array}$ & $\begin{array}{c}0.18 \pm \\
(0.15-0.21)\end{array}$ \\
\hline Turbidity (NTU) & $\begin{array}{c}3.57 \pm 1.80 \\
(1.6-5.8)\end{array}$ & $\begin{array}{c}1.78 \pm 0.82 \\
(0.6-2.5)\end{array}$ & $\begin{array}{c}7.0 \pm 2.65 \\
(0.7-7.0)\end{array}$ & $\begin{array}{c}4.52 \pm 3.58 \\
(0.7-8.4)\end{array}$ & $\begin{array}{c}6.17 \pm 3.45 \\
(2.8-9.2)\end{array}$ & $\begin{array}{c}6.75 \pm 1.60 \\
(4.4-8.0)\end{array}$ \\
\hline Nitrate $(\mathrm{mg} / \mathrm{l})$ & 0.035 & 0.021 & 0.165 & 0.191 & 0.97 & 1.315 \\
\hline Ortho-phosphate-P (mg/l) & $<0.01$ & $<0.01$ & $<0.01$ & $<0.01$ & $<0.01$ & $<0.01$ \\
\hline
\end{tabular}

Table 3. One-way analysis of variance (ANOVA) based on the differences of physicochemical variables among sites and seasons (Bold values indicate $p<0.05$ )

\begin{tabular}{c|c|c|c|c|c|c}
\hline \multirow{2}{*}{ Variable } & \multicolumn{3}{|c|}{ Site } & \multicolumn{3}{c}{ Season } \\
\cline { 2 - 7 } & MS & F & p-value & MS & F & p-value \\
\hline $\mathrm{pH}$ & 0.243 & 0.971 & 0.46 & 0.470 & 2.184 & 0.12 \\
Temperature & 2.952 & 0.286 & 0.91 & 56.469 & 36.069 & $<0.0001$ \\
Conductivity & 1982 & 0.337 & 0.88 & 7345 & 1.566 & 0.22 \\
TDS & 1695 & 1.376 & 0.27 & 1169 & 0.862 & 0.48 \\
DO & 0.710 & 0.710 & 0.90 & 1.178 & 1.573 & 0.23 \\
Salinity & 0.01 & 1.150 & 0.37 & 0.001 & 1.447 & 0.26 \\
Turbidity & 3525 & 0.61 & 0.70 & 22830 & 8.642 & $<0.001$ \\
\hline
\end{tabular}


Table 4. Families and the FFGs of macroinvertebrates from the Steelpoort River

\begin{tabular}{|c|c|c|c|c|c|c|c|c|c|}
\hline Order/Class & Family & Site 1 & Site 2 & Site 3 & Site 4 & Site 5 & Site 6 & Total & FFG \\
\hline \multirow{2}{*}{ Annelida } & Oligochaeta & 4 & 12 & 4 & 3 & 3 & 4 & 30 & $\mathrm{CG}$ \\
\hline & Hirudinea & 0 & 6 & 53 & 3 & 3 & 1 & 66 & $\mathrm{P}$ \\
\hline Plecoptera & Perlidae & 2 & 0 & 1 & 0 & 0 & 0 & 3 & $\mathrm{P}$ \\
\hline \multirow{6}{*}{ Ephemeroptera } & Baetidae & 376 & 281 & 462 & 73 & 218 & 537 & 1947 & CG \\
\hline & Caenidae & 3 & 2 & 1 & 0 & 0 & 1 & 7 & CG \\
\hline & Heptageniidae & 1 & 3 & 1 & 1 & 0 & 0 & 6 & $\mathrm{CG}$ \\
\hline & Leptophlebiidae & 165 & 4 & 17 & 7 & 0 & 0 & 193 & $\mathrm{CG}$ \\
\hline & Teloganodidae & 3 & 0 & 8 & 3 & 3 & 0 & 17 & CG \\
\hline & Tricorythidae & 5 & 2 & 2 & 0 & 6 & 1 & 16 & $\mathrm{CG}$ \\
\hline \multirow{5}{*}{ Odonata } & Synlestidae & 0 & 0 & 0 & 0 & 0 & 6 & 6 & $\mathrm{P}$ \\
\hline & Coenagrionidae & 57 & 41 & 308 & 7 & 12 & 29 & 454 & $\mathrm{P}$ \\
\hline & Aeshnidae & 0 & 11 & 0 & 68 & 21 & 48 & 148 & $\mathrm{P}$ \\
\hline & Gomphidae & 41 & 184 & 83 & 85 & 53 & 77 & 523 & $\mathrm{P}$ \\
\hline & Libellulidae & 3 & 66 & 52 & 81 & 104 & 208 & 514 & $\mathrm{P}$ \\
\hline \multirow{5}{*}{ Hemiptera } & Belostomatidae & 3 & 20 & 34 & 2 & 2 & 3 & 64 & $\mathrm{P}$ \\
\hline & Gerridae & 1 & 0 & 0 & 2 & 1 & 1 & 5 & $\mathrm{P}$ \\
\hline & Hydrometridae & 0 & 0 & 3 & 0 & 1 & 0 & 4 & $\mathrm{P}$ \\
\hline & Naucoridae & 13 & 3 & 1 & 8 & 2 & 10 & 37 & $\mathrm{P}$ \\
\hline & Veliidae & 67 & 6 & 2 & 3 & 1 & 257 & 336 & $\mathrm{P}$ \\
\hline \multirow{5}{*}{ Trichoptera } & Ecnomidae & 1 & 7 & 4 & 36 & 40 & 19 & 107 & $\mathrm{P} / \mathrm{CG}$ \\
\hline & Hydropsychidae & 155 & 44 & 113 & 239 & 402 & 187 & 1140 & $\mathrm{CF}$ \\
\hline & Philopolamidae & 0 & 0 & 4 & 0 & 0 & 0 & 4 & $\mathrm{CF}$ \\
\hline & Psychomyiidae & 6 & 2 & 4 & 0 & 0 & 2 & 14 & $\mathrm{P}$ \\
\hline & Hydroptilidae & 0 & 5 & 4 & 0 & 0 & 1 & 10 & $\mathrm{Sc} / \mathrm{P}$ \\
\hline \multirow{5}{*}{ Coleoptera } & Dytiscidae & 3 & 3 & 6 & 1 & 1 & 26 & 40 & $\mathrm{P}$ \\
\hline & Elmidae & 9 & 7 & 21 & 71 & 32 & 26 & 166 & $\mathrm{CG} / \mathrm{Sc} / \mathrm{Sh}$ \\
\hline & Gyrinidae & 1 & 5 & 3 & 2 & 6 & 3 & 20 & $\mathrm{P}$ \\
\hline & Helodidae & 1 & 1 & 5 & 0 & 0 & 0 & 7 & Sh \\
\hline & Hydrophilidae & 0 & 0 & 4 & 0 & 0 & 3 & 7 & $\mathrm{P}$ \\
\hline \multirow{7}{*}{ Diptera } & Athericidae & 0 & 0 & 2 & 1 & 0 & 0 & 3 & $\mathrm{P}$ \\
\hline & Chironomidae & 9 & 1 & 3 & 63 & 45 & 62 & 183 & $\mathrm{CG}$ \\
\hline & Muscidae & 2 & 1 & 0 & 4 & 3 & 5 & 15 & $\mathrm{P}$ \\
\hline & Psychodidae & 0 & 0 & 1 & 0 & 0 & 3 & 4 & $\mathrm{CG}$ \\
\hline & Simuliidae & 22 & 208 & 25 & 103 & 208 & 45 & 611 & $\mathrm{CF}$ \\
\hline & Tabanidae & 16 & 30 & 17 & 41 & 10 & 20 & 134 & $\mathrm{P}$ \\
\hline & Tipulidae & 1 & 0 & 3 & 0 & 0 & 0 & 4 & $\mathrm{Sh} / \mathrm{CG} / \mathrm{P}$ \\
\hline \multirow{4}{*}{ Gastropoda } & Lymnaeididae & 0 & 2 & 7 & 0 & 1 & 4 & 14 & $\mathrm{Sc}$ \\
\hline & Physidae & 0 & 1 & 22 & 0 & 0 & 16 & 39 & $\mathrm{Sc}$ \\
\hline & Planorbinae & 0 & 1 & 5 & 0 & 0 & 3 & 9 & $\mathrm{Sc}$ \\
\hline & Thiaridae & 0 & 223 & 66 & 15 & 0 & 0 & 304 & $\mathrm{Sc}$ \\
\hline Lepidoptera & Pyralidae & 0 & 1 & 0 & 0 & 2 & 0 & 3 & Sh \\
\hline Total & & 970 & 1183 & 1351 & 922 & 1180 & 1608 & 7214 & \\
\hline
\end{tabular}

\section{Relationship between macroinvertebrates and physicochemical variables}

Based on CCA carried out for individual variables, $\mathrm{pH}$, EC, TDS, DO, temperature, salinity and turbidity were found to have a significant effect on macroinvertebrate community structure (Fig. 3). Site 1 was characterized by high temperature and $\mathrm{pH}$ and the macroinvertebrates that were associated with this site included Baetidae, Leptophlebiidae and Perlidae, which are sensitive to pollution. Sites 5 and 6 were characterized by conductivity, TDS, nitrate and salinity and associated with both 
sensitive and tolerant taxon, such as Aeshnidae, Ecnomidae and Chironomidae. The first and second axes of the CCA analysis accounted for $35.5 \%$ and $58.8 \%$ variance (Table 5).

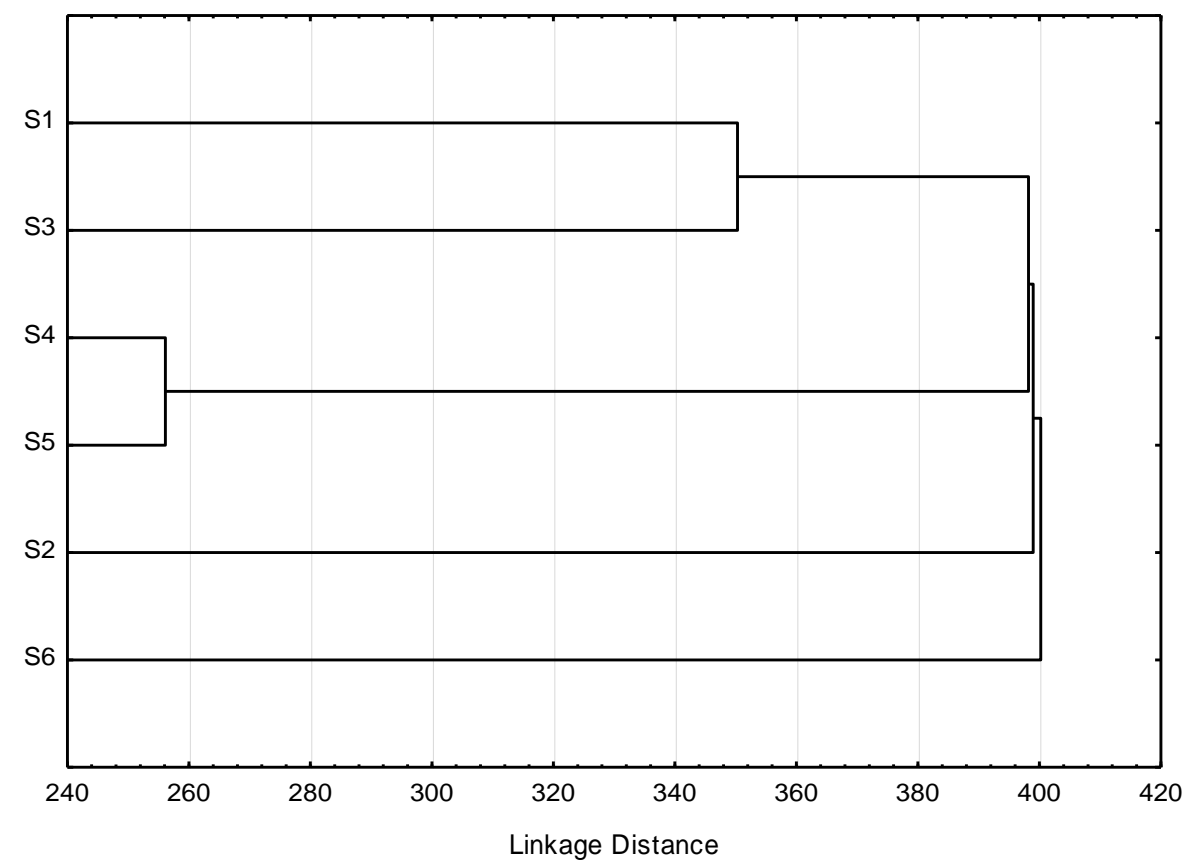

Figure 2. Dendrogram showing the hierarchical cluster analysis of aquatic macroinvertebrate assemblages among the sampling site, with the following groupings; S1 and S3, S4 and S5, S2 and S6)

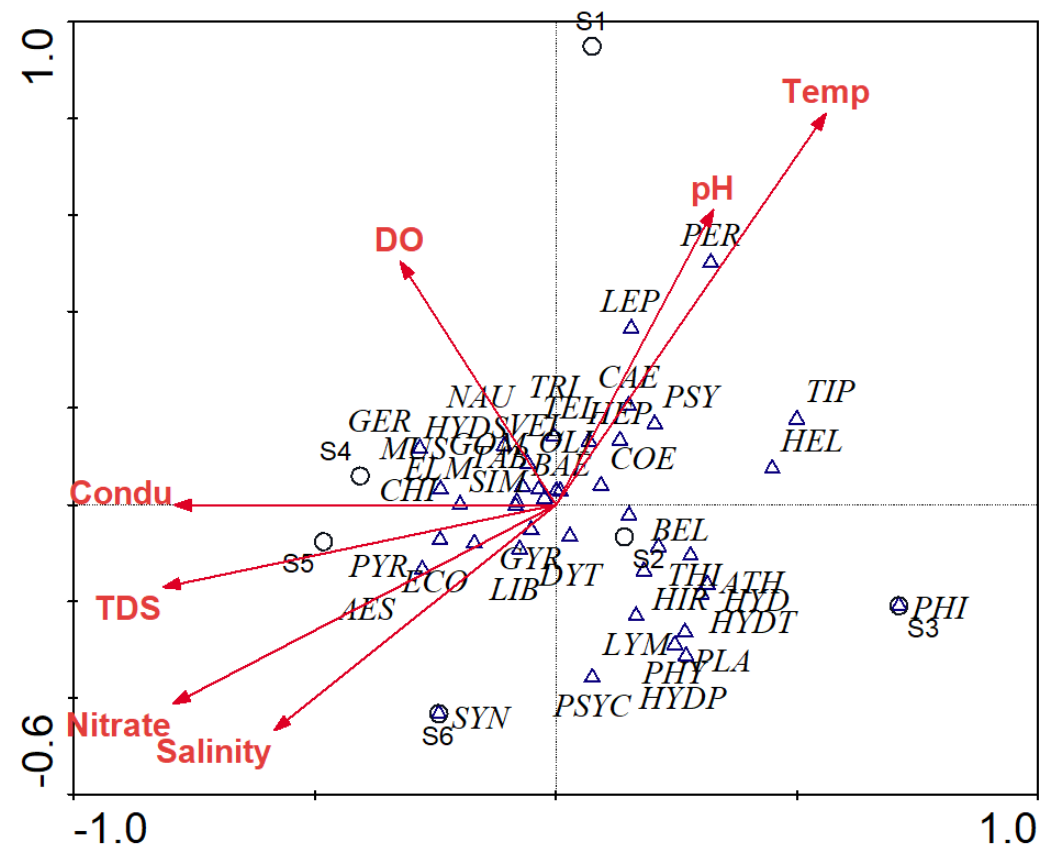

Figure 3. CCA plots showing the relationship between measured environmental variables with macroinvertebrate families and sampling sites (abbreviations for macroinvertebrate families are in Table 2) 
Table 5. The canonical correspondence analysis (CCA) between functional feeding groups and environmental variables for Dwars and Spekboom rivers

\begin{tabular}{c|c|c|c|c|c}
\hline Eigenvalues: & 0.131 & 0.087 & 0.081 & 0.044 & 0.370 \\
\hline Taxa-environment correlations: & 1.000 & 1.000 & 1.000 & 1.000 & \\
\hline \% cumulative variance: & 35.5 & 58.8 & 80.7 & 92.5 & \\
\hline of taxa-environment: & 35.5 & 58.8 & 80.7 & 92.5 & \\
\hline Sum of all eigenvalues & & & & & 0.370 \\
\hline
\end{tabular}

\section{Functional feeding groups}

The collector-gatherers were the most abundant functional feeding group at Site 1, collector-filterers were the most dominant group at Site 4 and Site 5, predators were the most dominant group at Site 2, Site 3 and Site 6 (Fig. 4). Shredders were least represented at all sites of the river. The collector-gatherers made up of $34.82 \%$, followed by predators (33.96\%), collector-filterers (24.33\%), scrapers (5.89\%), and then shredders (1.00\%). The abundance of collector-gatherers and predators increased at Site 6 (Table 6). There was less variation in abundance of predators among the sites as compared to the other groups. Seasonally, the collector-gatherers were dominant in winter, collector-filterers were dominant in spring and predators were the dominant group in autumn and summer (Table 7). The highest seasonal composition was in winter (34.79\%), followed by autumn (32.80\%), spring (2312\%) and then summer (9.29\%) (Fig. 5). The abundance of collector-gatherers increased in winter, collector-filterers and shredders in spring, predators and scrapers increased in autumn. However, there were no significant variations in terms of distribution of the FFGs among seasons $(\mathrm{p}>0.05)$.

Table 6. Relative abundance of functional feeding groups of macro invertebrates at the various sites in the Steelpoort River. The functional feeding groups (FFG)-Filterers (Ft), collector-gatherers $(C G)$, predators (Pr), scrappers (Sc) and shredders (Sh)

\begin{tabular}{c|c|c|c|c|c|c|c}
\hline Site & CF & CG & P & Sc & Sh & Total & $\begin{array}{c}\text { Relative } \\
\text { abundance (\%) }\end{array}$ \\
\hline 1 & 177 & 570 & 215 & 3 & 5 & 920 & 13.45 \\
2 & 252 & 311 & 383 & 232 & 5 & 1183 & 16.40 \\
3 & 142 & 509 & 578 & 109 & 13 & 1351 & 18.72 \\
4 & 342 & 191 & 326 & 38 & 25 & 922 & 12.78 \\
5 & 610 & 305 & 240 & 11 & 14 & 1180 & 16.36 \\
6 & 232 & 626 & 708 & 32 & 10 & 1608 & 22.29 \\
\hline Total & 1755 & 2512 & 2450 & 425 & 72 & 7214 & 100 \\
\hline Relative abundance (\%) & 24.33 & 34.82 & 33.96 & 5.89 & 1.00 & 100 & \\
\hline
\end{tabular}

Table 7. Functional feeding groups of macroinvertebrates collected during different seasons in the Steelpoort River. The functional feeding groups $(F F G)$-Filterers (Ft), collectorgatherers $(C G)$, predators $(\mathrm{Pr})$, scrappers $(\mathrm{Sc})$ and shredders $(\mathrm{Sh})$

\begin{tabular}{c|c|c|c|c|c}
\hline FFG & Summer & Autumn & Winter & Spring & Total \\
\hline CF & 71 & 558 & 398 & 728 & 1755 \\
CG & 144 & 799 & 1252 & 317 & 2512 \\
P & 310 & 842 & 774 & 525 & 2451 \\
Sc & 129 & 151 & 78 & 68 & 426 \\
Sh & 16 & 16 & 8 & 30 & 70 \\
\hline Total & 670 & 2366 & 2510 & 1668 & 7214 \\
\hline
\end{tabular}




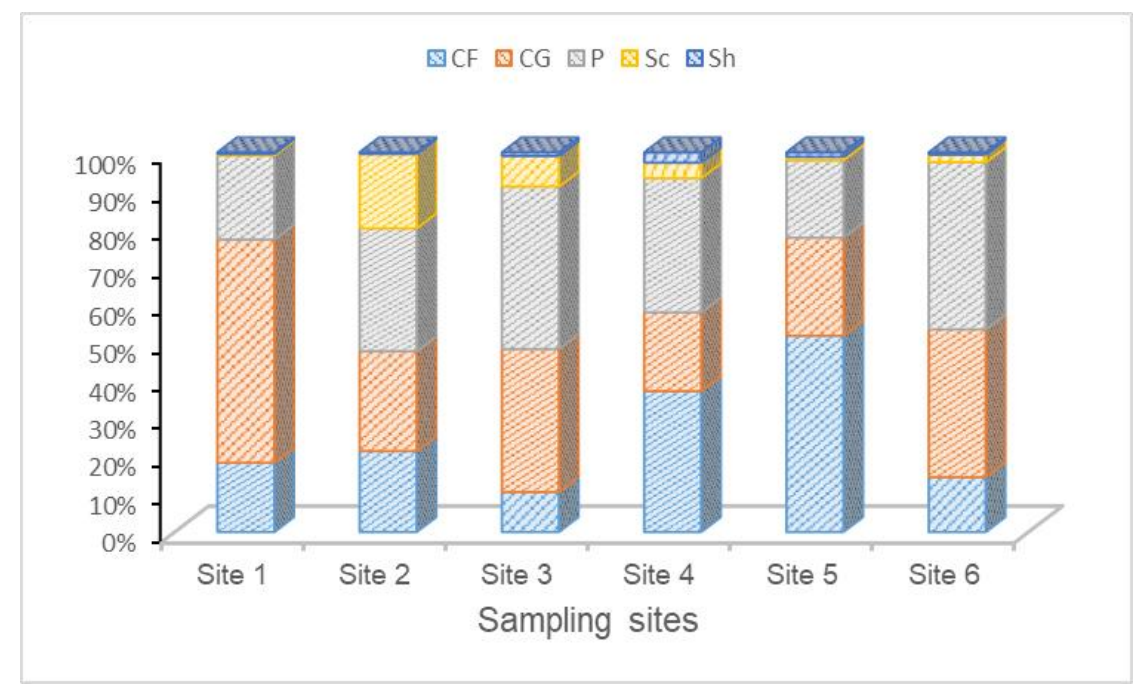

Figure 4. Composition of the functional feeding groups of aquatic macroinvertebrates in the Steelpoort River

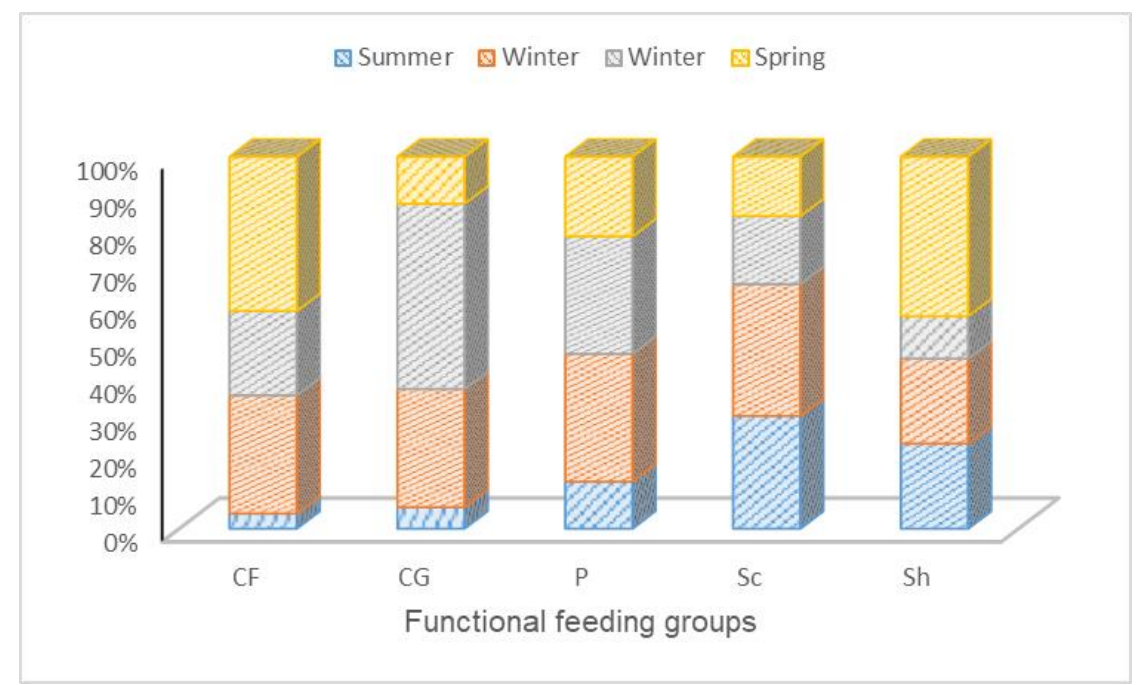

Figure 5. Seasonal composition of the FFGs of aquatic macroinvertebrates in the Steelpoort River

The CCA tri-plot of the selected water quality variables (physicochemical parameters and nutrients) showed that collector-gatherers and collector-filterers were associated with turbidity, ammonium, salinity, TDS and conductivity, predators with nitrite, phosphate and velocity and scrapers were associated with depth, and shredders were associated with temperature (Fig. 6).

\section{Discussion}

\section{Physicochemical variables}

Most of the physicochemical variable changed relatively little across sites with more variables changing across seasons. The mean value of water temperature was found 
within the permissible limits, which was between 25 and $30{ }^{\circ} \mathrm{C}$ (DWAF, 1996). The highest mean DO was recorded at Site 6 which had the lowest mean temperature, as solubility of oxygen increases with decreasing temperature. The high DO could also be from photosynthesis due to high exposure to sunlight and high stream velocity (Connollym et al., 2004). Site 6 had less canopy cover that could have facilitated more sunlight reaching the water for photosynthesis. Significant increase in conductivity, TDS, salinity, turbidity and nitrate at the downstream sites, Sites 5 and 6, could be attributed to increase flow discharge and flooding from other parts of the river. High TDS levels are known to occur in streams draining mining sites after large volumes of rock are exposed to weathering elements such as air and water, causing rapid dissolution of rocks and minerals into waters draining the site (Bernhardt et al., 2012).

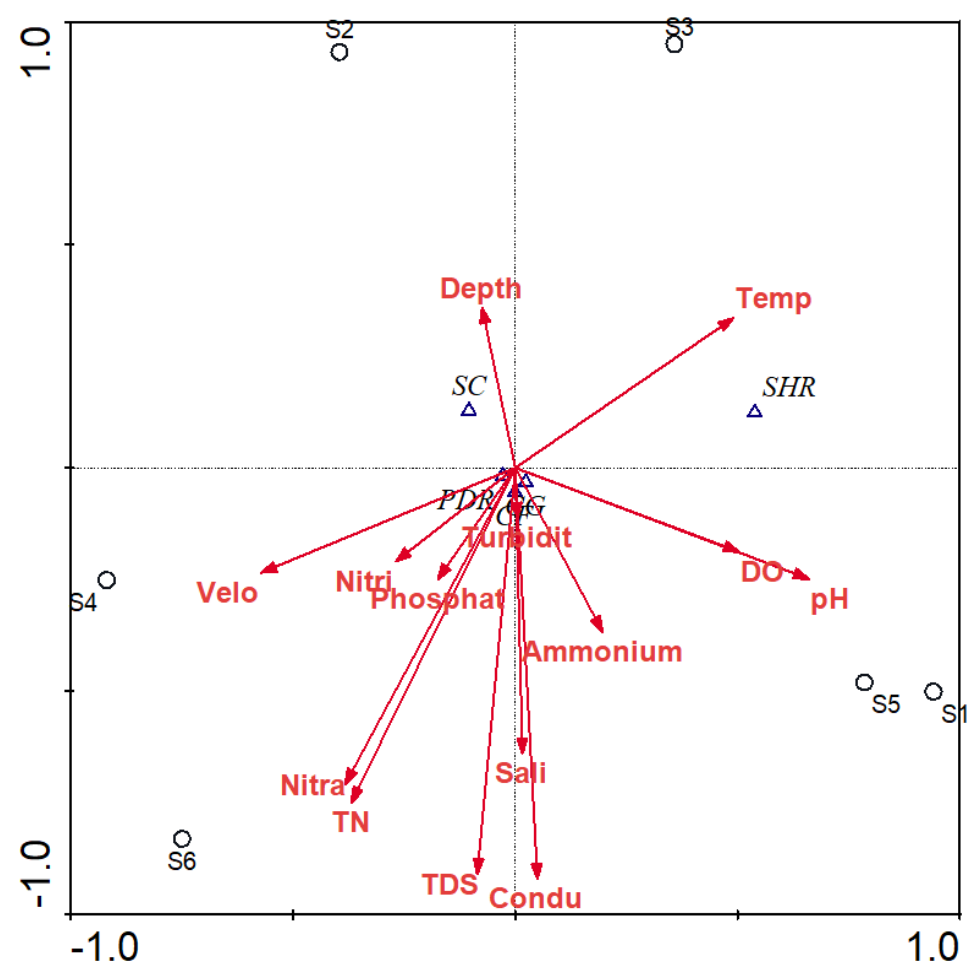

Figure 6. CCA tri-plot shows the relationship between FFG and physicochemical parameters at the Steelpoort River

In areas of human settlement, such as Site 5 and Site 6, TDS is increased by pollution from sewage, urban runoff and industrial wastewater. Water with TDS less than 400 $\mathrm{mg} / \mathrm{l}$ as observed in this study is generally considered to be good water (WHO, 2004). However, the downstream of the river needs to be monitored as it has potential for disturbing the ecosystem integrity if it continues to increase. For nitrate, the high concentration at Site 5 and Site 6 could be due to sewage (and industrial effluents) and storm water runoff. Several studies have shown that urban streams worldwide are often polluted by runoff and combined sewer outflows (Bere and Nyamupingidza, 2014).

\section{Macroinvertebrates}

There was spatial variation of macroinvertebrate assemblages. The sites with strong anthropogenic pressures had lower abundances than less impacted sites. The variation 
among the sites in macroinvertebrate abundance could be due to the variation in the physicochemical factors which favours their survival and perhaps due to the presence of high organic matter within the site (Sharma et al., 2013). The high abundance of macroinvertebrates at Site 2 and Site 6 could be due to the relatively good water quality the Steelpoort River receives from the Dwars and Spekboom rivers respectively. This shows the importance of tributaries in restoring main stream ecosystem. However, the high abundance at Site 3 could be due to the presence of different biotopes. The family with the highest abundance at all the sites except Site 4 and Site 5 was Baetidae. Baetidae has a cosmopolitan distribution and represents a quarter of the Ephemeroptera diversity worldwide both at generic and specific levels (Gattolliat and Nieto, 2009; Sartori and Brittain, 2015).

Hierarchical cluster analysis showed three groups. Cluster I was composed of Site 1 and Site 3, this could be due to agricultural activities near both sites, cluster II, was composed of Site 2 and Site 6, both sites receive water of relatively good quality from Dwars and Spekboom respectively, and cluster III, Site 4 and Site 5 were more affected by mining and municipal waste waters. Thus, the human activities in the catchment affected the water quality and hence the distribution of the macroinvertebrates. The CCA analysis revealed a correlation between the aquatic macroinvertebrate taxa and water quality. Cumulative percentage variance of taxa-environmental variable relations for axis 1 and 2 was $58.8 \%$. This is an indication that no single environmental variable fully explained taxon composition and distribution pattern across the sites (Niba and Sakwe, 2018).

Seasonally, the highest abundance of macroinvertebrates was in winter (dry season). This confirms the assertion that temperature is a dominant factor in the seasonal structuring of the macroinvertebrate community (Beltrán et al., 2011; Hudu and Rawi, 2019). Thus, in dry seasons, macroinvertebrates have greater possibilities of colonising the river area, since the habitat becomes homogenised and their densities and specific richness can increase (Reynaga and Dos Santos, 2013). In summer (rainy season), with high precipitation and flooding, some of the macroinvertebrates' habitats could have been destroyed and some drifted to downstream. Studies by Gualdoni and Oberto (2012) found that in rainy seasons, when the water flow increases due to the high level of precipitation, macroinvertebrates are drifted downstream.

\section{Functional feeding groups}

The collector-gatherers were the most dominant functional feeding group. The predominance of collector-gatherers is attributed to their ecological plasticity and capacity for the occupation of rapid water environments (Brasil et al., 2014) and their ability to occupy in a broad variety of habitats (Castro et al., 2016). The collectorfilterers and collector-gatherers together made up of more than $50 \%$ of the total macroinvertebrates recorded. Collectors are commonly abundant in streams and typically increase in abundance with stream size (Vannote et al., 1980). The predators were well distributed along the whole river and could be due to availability of food and less competition (Ono et al., 2020). Predators normally have a similar proportion throughout the length of a stream channel, according to the river continuum concept or, alternatively, their abundance may depend on prey availability (Vannote et al., 1980). Similar to other studies, the predator distribution was almost similar at all sites. Scraper abundance can be related to algal primary production, which is in turn affected by available nutrients and light. 
The low numbers of shredders in the river could be due to the fact that effective microbial activities replace shredder activity at high temperatures (Kaboré et al., 2016; Madomguia et al., 2016). The highest abundance of scrapers at S2 could be due to the open canopy causing more sunlight to reach the water for photosynthesis. This also explains the scarcity of shredders at S1 and S2 due to less riparian canopy to provide enough leaf litter as an energy source. Human activities have contributed to the loss of riparian vegetation along the river. Similar results have been reported that shredders are intimately related to the riparian vegetation, because of their reliance on allochthonous feeding resources (Brasil et al., 2014; Masese et al., 2014). The low numbers of shredders and scrapers could also be due to the fact that these two groups are more sensitive to disturbances, while collector-gatherers and collector-filterers are more tolerant to pollution that might alter the availability of certain food (Barbour et al., 1996). It has even been found that some taxa can shift their feeding in response to changes in land use and riparian conditions (Benstead and Pringle, 2004; Li and Dudgeon, 2008). Thus, the functional groups can potentially be used to assess aquatic ecosystem health (Bhawsar et al., 2015; Fu et al., 2016).

Seasonally, the highest taxon abundance was in winter. Winter is the drier season of the year in the study area hence, the river receives less runoff draining from the catchment. In general, factors driving macroinvertebrate seasonal variation include precipitation/discharge, temperature, and photoperiod, and each of these factors can influence disturbance regimes in streams (Bêche et al., 2006). Seasonal variation of macroinvertebrate distribution can also be caused by changes in current velocity, substrate type and organic matter.

According to the continuum river concept, low order rivers such as the Steelpoort River should contain mainly collector-gatherers and shredder organisms (Vannote et al., 1980). However, in this study the predominant group was the predators and collectorgatherers, and the least predominant group was the shredders. The RCC states that the shredders should dominate among the functional feeding groups when the source of the river is within a shaded area (Vannote et al., 1980). The riparian zone of this particular river has been disturbed due to anthropogenic activities. Shredders are intimately related with the riparian vegetation, given their dependence on allochthonous feeding resources (Allan and Castillo, 2007). The high diversity and non-compliance of many tropical rivers to the Vannote's RCC model have also been observed by other studies (e.g. Masese et al., 2014; Brasil et al., 2014; Doong et al., 2021). Removal of indigenous vegetation is known to deplete the allochthonous resources of a river and therefore reduces shredder abundance (Minaya et al., 2013). The most noticeable impact observed during this study was pipeline construction which has resulted in the removal of riparian vegetation and causing erosion of stream banks along the river. This has contributed to the sediment loads entering the river and therefore reduction in microhabitats for the macroinvertebrates. Substrate heterogeneity positively affects the richness and functional diversity of macroinvertebrate communities (Milesi et al., 2016). In many parts of the world, land use change, particularly loss of riparian vegetation, has resulted in loss of diversity and major shifts in the structural and functional organization of macroinvertebrates in streams (Jinggut et al., 2012; Silva-Araújo et al., 2020; AddoBediako, 2021). 


\section{Conclusion}

The variations of macroinvertebrate community structure observed could be attributed to land-use changes that affected water quality of the river. There was no trend of distribution of macroinvertebrates which emphasized that localized disturbance had an influence on their distribution. Predators, collector-gatherers and collectorfilterers dominated throughout the river. This finding partially agrees with the RCC prediction that midstream should be co-dominated by collectors (collector-gatherers and collector-filterers) and scrapers. The downstream site (Site 6) was also dominated by the collectors, which agree with the prediction of the RCC. The low number of shredders in the river especially at the upstream sites is an indication of degradation in the catchment especially loss of riparian vegetation. The highest abundance of FFG in winter indicates seasonal variation in water quality. The study shows that ecosystem function can be altered by changes in environmental factors and FFG composition could also be used as an indicator of ecosystem change. Thus, the human activities in the catchment of the Steelpoort River is affecting the river and the aquatic biota, such as the macroinvertebrate communities. There is a need therefore to develop an effective and sustainable water quality monitoring programme for the river. Future studies should include broader consequence of land use changes and climate change on ecosystem functioning and functional mechanism of macroinvertebrates.

Acknowledgements. We are grateful to South Africa National Research Foundation (NRF) for providing financial support for study.

Conflict of interests. The authors declare that they have no conflicts of interests.

\section{REFERENCES}

[1] Addo-Bediako, A. (2020): Assessment of heavy metal pollution in the Blyde and Steelpoort Rivers of the Olifants River System, South Africa. - Polish Journal of Environmental Studies 29(5): 3023-3039.

[2] Addo-Bediako, A. (2021): Spatial distribution patterns of benthic macroinvertebrate functional feeding groups in two rivers of the Olifants River System, South Africa. Journal of Freshwater Ecology 36(1): 97-109.

[3] Allan, J. D., Castillo, M. M. (2007): Stream Ecology: Structure and Function of Running Waters. - Springer, Dordrecht.

[4] Ashton, P. J., Dabrowski, J. M. (2011): An overview of water quality and the causes of poor water quality in the Olifants River Catchment. - WRC Project No. K8/887. Water Research Commission, Pretoria.

[5] Barbour, M., Gerritsen, J., Griffith, G., Frydenborg, R., Mccarron, E., White, J., Bastian, M. (1996): A framework for biological criteria for Florida streams using benthic macroinvertebrates. - Journal of the North American Benthological Society 15(2): 185211.

[6] Bêche, L. A., Mcelravy, E. P., Resh, V. H. (2006): Long-term seasonal variation in the biological traits of benthic-macroinvertebrates in two Mediterranean climate streams in California, U.S.A. - Freshwater Biology 51: 56-75.

[7] Beltrán, L., Miserendino, M. L., Pessacq, P. (2011): Life history, seasonal variation and production of Andesiops torrens (Lugo-Ortiz \& McCafferty) and Andesiops peruvianus (Ulmer) (Ephemeroptera: Baetidae) in a headwater Patagonian stream. - Limnologica 41: $57-62$. 
[8] Benstead, J. P., Pringle, C. M. (2004): Deforestation alters the resource base and biomass of endemic stream insects in eastern Madagascar. - Freshwater Biology 49: 490-501.

[9] Bere, T., Nyamupingidza, B. (2014): Use of biological monitoring tools beyond their country of origin: a case study of the South African Scoring System Version 5 (SASS5). - Hydrobiologia 722: 223-232.

[10] Bernhardt, E. S., Lutz, B. D., King, R. S., Fay, J. P., Carter, C. E., Helton, A. M., Campagna, D., Amos, J. (2012): How many mountains can we mine? Assessing the regional degradation of Central Appalachian rivers by surface coal mining. Environmental Science and Technology 46: 8115-8122.

[11] Bhawsar, A., Bhat, M. A., Vyas, V. (2015): Distribution and composition of macroinvertebrates functional feeding groups with reference to catchment area in Barna Sub-Basin of Narmada River Basin. - International Journal of Scientific Research and Engineering Studies 3(11): 385-393.

[12] Brasil, S., Juen, L., Batista, J. D., Pavan, M. G., Cabette, H. S. R. (2014): Longitudinal distribution of the functional feeding groups of aquatic insects in streams of the Brazilian Cerrado Savanna. - Neotropical Entomology 43: 421-428.

[13] Castro, D. M. P., Carvalho, D. R., Pompeu, P. S., Moreira, M. Z., Nardoto, G. B., Callisto, M. (2016): Land use influences niche size and the assimilation of resources by benthic macroinvertebrates in tropical headwater streams. - PLoS One 11: 1-19.

[14] Castro, D. M. P., Dolédec, S., Callisto, M. (2018): Land cover disturbance homogenizes aquatic insect functional structure in neotropical savanna streams. - Ecological Indicators 84: 573-582.

[15] Chen, N., Chen, L., Ma, Y., Chen, A. (2019): Regional disaster risk assessment of China based on self-organizing map: clustering, visualization and ranking. - International Journal of Disaster Risk Reduction 33: 196-206.

[16] Connollym, N. M., Crossland, R., Pearson, R. G. (2004): Effect of low dissolved oxygen on survival, emergence, and drift of tropical stream macroinvertebrates. - Journal of the North American Benthological Society 23(2): 251-270.

[17] Cummins, K. W. (2018): Functional Analysis of Stream Macroinvertebrates. - In: Gokce, D. (ed.) Limnology. IntechOpen, London. DOI: 10.5772/intechopen.79913.

[18] Cummins, K. W., Merritt, R. W., Andrade, P. C. N. (2005): The use of macroinvertebrate functional groups to characterize ecosystem attributes in selected streams and rivers in south Brazil. - Studies on Neotropical Fauna Environment 40(1): 69-89.

[19] Dallas, H. F. (2007): The influence of biotope availability on macroinvertebrate assemblages in South African Rivers: implications for aquatic bioassessment. Freshwater Biology 52: 370-380.

[20] Dalu, T., Wasserman, R. J., Tonkin, J. D., Mwedzi, T., Magoro, M. L., Weyl, O. L. F. (2017): Water or sediment? Partitioning the role of water column and sediment chemistry as drivers of macroinvertebrate communities in an austral South African stream. Science of the Total Environment 607-608: 317-325.

[21] Department of Water Affairs and Forestry (DWAF) (1995): Middle Steelpoort Catchment, Groundwater Management Plan. - DWAF, Pretoria.

[22] Department of Water Affairs and Forestry (DWAF) (1996): South African Water Quality Guidelines. Volume 7: Aquatic Ecosystems. Second Ed. - DWAF, Pretoria.

[23] Doong, M. K. T., Anticamara, J. A., Magbanua, F. S. (2021): Spatial variations in the distribution of benthic macroinvertebrate functional feeding groups in tropical rivers. Indonesian Journal of Limnology 2(1): 35-52.

[24] Ferreira, V., Encalada, A. C., Graça, M. A. S. (2012): Effects of litter diversity on decomposition and biological colonization of submerged litter in temperate and tropical streams. - Freshwater Science 31: 945-962.

[25] Fierro, P., Bertrán, C., Tapia, J., Hauenstein, E., Peña-Cortés, F., Vergara, V., Cerna, C., Vargas-Chacoff, L. (2017): Effects of local land-use on riparian vegetation, water quality, 
and the functional organization of macroinvertebrate assemblages. - Science of the Total Environment 609: 724-734.

[26] Fu, L., Jiang, Y., Ding, J., Liu, Q., Peng, Q. Z., Kang, M. Y. (2016): Impacts of land use and environmental factors on macroinvertebrate functional feeding groups in the Dongjiang River basin, southeast China. - Journal of Freshwater Ecology 31(1): 21-35.

[27] Gattolliat, J. L., Nieto, C. (2009): The family Baetidae (Insecta: Ephemeroptera): synthesis and future challenges. - Aquatic Insects 31: 41-62.

[28] Gerber, A., Gabriel, M. J. M. (2002): Aquatic Invertebrates of South African Rivers: Field Guide. - Resource Quality Services, Department of Water Affairs and Forestry, Pretoria.

[29] Gualdoni, C. M., Oberto, A. M. (2012): Estructura de la comunidad de macroinvertebrados del arroyo Achiras (Córdoba, Argentina): análisis previo a la construcción de una presa. - Iheringia Serie Zoologia 102: 177-186.

[30] Hudu, A. N., Rawi, C. S. M. (2019): Functional Feeding Group (FFG) of Aquatic Macroinvertebrate in Middle Reach of Kerian River Basin of North Malaysia Peninsula. - Tropical Life Sciences Research 30(2): 1-12.

[31] Jinggut, T., Yule, C. M., Boyero, L. (2012): Stream ecosystem integrity is impaired by logging and shifting agriculture in a global megadiversity center (Sarawak, Borneo). Science of the Total Environment 437: 83-90.

[32] Jun, Y-C., Kim, N-Y., Kim, S-H., Park, Y-S., Kong, D-S., Hwang, S-J. (2016): Spatial distribution of benthic macroinvertebrate assemblages in relation to environmental variables in Korean Nationwide streams. - Water 8(1): 27.

[33] Kaboré, I., Moog, O., Alp, M., Guenda, W., Koblinger, T., Mano, K., Ouéda, A., Ouédraogo, R., Trauner, D. and Melcher, A. H. (2016): Using macroinvertebrates for ecosystem health assessment in semi-arid streams of Burkina Faso. - Hydrobiologia 766: 57-74.

[34] Kim, D-H., Chon, T-S., Kwak, G-S., Lee, S-B., Park, Y-S. (2016): Effects of land use types on community structure patterns of benthic macroinvertebrates in streams of urban areas in the South of the Korea Peninsula. - Water 8(5): 187.

[35] Kruskal, J. B. (1964): Multidimensional scaling by optimising goodness of fit to a nonmetric hypothesis. - Psychometrica 29: 1-27.

[36] Li, A. O. Y., Dudgeon, D. (2008): Food resources of shredders and other benthic macroinvertebrates across a range of shading conditions in tropical Hong Kong streams. Freshwater Biology 53: 2011-2025.

[37] Li, L., Zheng, B., Liu, L. (2010): Biomonitoring and bioindicators used for river ecosystems: definitions, approaches and trends. - Procedia Environmental Sciences 2: 1510-1524.

[38] Li, H., You, S., Zhang, H., Zheng, W., Zou, L. (2018): Investigating the environmental quality deterioration and human health hazard caused by heating emissions. - Science of the Total Environment 628: 1209-1222.

[39] Madomguia, D., Zebaze, T. S. H. and Fomena, A. (2016): Macro invertebrates functional feeding groups, Hilsenhoff biotic index, percentage of tolerant taxa and intolerant taxa as major indices of biological assessment in ephemeral stream in Sudano-Sahelian zone (Far-North, Cameroon). - International Journal of Current Microbiology and Applied Sciences 5: 792-806.

[40] Masese, F. O., Kitaka, N., Kipkemboi, J., Gettel, G. M., Irvine, K., McClain, M. E. (2014): Macroinvertebrate functional feeding groups in Kenyan highland streams: evidence for a diverse shredder guild. - Freshwater Science 33: 435-450.

[41] Meira, B. R., Progênio, M., Leite, E. C., Lansac-Tôha, F. M., Durán, C. L. G., Jati, S., Rodrigues, L. C., Lansac-Tôha, F. A., Velho, L. F. M. (2021): Functional feeding groups of Protist Ciliates (Protist: Ciliophora) on a neotropical flood plain. - Annales de Limnologie International Journal of Limnology 57: 13. 
[42] Merritt, R. W., Cummins, K. W., Berg, M. B. (2017): Trophic Relationships of Macroinvertebrates. Chap. 20. - In: Hauer, F. R., Lamberti, G. A. (eds.) Methods in Stream Ecology. Academic Press (Elsevier), London, pp. 413-433.

[43] Milesi, S. V., Dolédec, S., Melo, A. S. (2016): Substrate heterogeneity infuences the trait composition of stream insect communities: an experimental in situ study. - Freshwater Science 35: 1321-1329.

[44] Minaya, V., McClain, M. E., Moog, O., Omengo, F., Singer, G. A. (2013): Scaledependent effects of rural activities on benthic macroinvertebrates and physico-chemical characteristics in headwater streams of the Mara River, Kenya. - Ecological Indicators 32: 116-122.

[45] Munyika, S., Kongo, V., Kimwaga, R. (2014): River health assessment using macroinvertebrates and water quality parameters: a case of the Orange River Namibia. Physics and Chemistry of the Earth 76: 140-148.

[46] Niba, A., Sakwe, S. (2018): Turnover of benthic macroinvertebrates along the Mthatha River, Eastern Cape, South Africa: implications for water quality bio-monitoring using indicator species. - Journal of Freshwater Ecology 33: 157-171.

[47] Ono, E. R., Manoel, P. S., Melo, A. L. U., Uieda, V. S. (2020): Effects of riparian vegetation removal on the functional feeding group structure of benthic macroinvertebrate assemblages. - Community Ecology 21: 145-157.

[48] Príncipe, R., Gualdoni, C., Oberto, A., Raffaini, G., Corigliano, M. (2010): Spatialtemporal patterns of functional feeding groups in mountain streams of Córdoba, Argentina. - Ecologia Austral 20: 257-268.

[49] Ramirez, A., Gutiérrez-Fonseca, P. E. (2014): Functional feeding groups of aquatic insect families in Latin America: a critical analysis and review of existing literature. - Revista de Biologia Tropical 62: 155-167.

[50] Rasifudi, L., Addo-Bediako, A., Swemmer, A., Bal, K. (2018): Distribution and diversity of benthic macroinvertebrates in the Selati River of Olifants River System, South Africa. - African Entomology 26: 398-406.

[51] Reynaga, M. C., Dos Santos, D. A. (2013): Contrasting taxonomical and functional responses of stream invertebrates across space and time in a Neotropical basin. Fundamental and Applied Limnology 183: 121-133.

[52] Santhosh, S. K., Ashadevi, R. (2017): Biomonitoring as a strategy for ecosystem healtha case study at the upper reaches of Vamanapuram River, Kerala. - International Journal of Science and Research 6: 750-754.

[53] Sartori, M., Brittain, J. E. (2015): Order Ephemeroptera. - In: Thorp, J. H., Rogers, D. C. (eds.) Thorp and Covich's Freshwater Invertebrates. 4th Ed. Vol. I. Ecology and General Biology. Academic Press, Cambridge, MA.

[54] Sharma, K. K., Antal, N., Kour, S., Devi, A., Sharma, V. (2013): Biodiversity and Abundance of benthic macroinvertebrates communities of Datta-Da-Talab Pond, Birpur, India. - International Multidisciplinary Research Journal 3: 13-17.

[55] Silva-Araújo, M., Silva-Junior, E. F., Neres-Lima, V., Feijó-Lima, R., Tromboni, F., Lourenco-Amorim, C., Thomas, S. A., Moulton, T. P., Zandonà, E. (2020): Effects of riparian deforestation on benthic invertebrate community and leaf processing in Atlantic forest streams. - Perspectives in Ecology and Conservation 18: 277-282.

[56] Stimie, C., Richters, E., Thompson, H., Perret, S., Matete, M., Abdallah, K., Kau, J., Mulibana, E. (2001): Hydro-Institutional Mapping in the Steelpoort River Basin, South Africa. - Working Paper 17 (South Africa Working Paper No. 6). International Water Management Institute. Colombo.

[57] Ter Braak, C. J. F. and Smilauer, P. (2002): CANOCO Reference Manual and CanoDraw for Windows User's Guide: Software for Canonical Community Ordination (version 4.5). - Biometris, Wageningen. 
[58] Vannote, R. L., Minshall, G. W., Cummins, K. W., Sedell, J. R., Cushing, C. E. (1980): The river continuum concept. - Canadian Journal of Fisheries and Aquatic Sciences 37: 130-137.

[59] Van Veelen, M., Dhemba, N. (2011): Development of reconciliation strategy for the Olifants River water supply. - Water Quality Report No. PWMA04/B50/00/8310/7, South Africa. P76.

[60] WHO (World Health Organization Standard for Drinking Water) (2004): Guidelines for Drinking Water Quality Vol. 1 Recommendation. - France.

[61] Wright, I., Ryan, M. (2016): Impact of mining and industrial pollution on stream macroinvertebrates: importance of taxonomic resolution, water geochemistry and EPT indices for impact detection. - Hydrobiologia 772: 103-115. 